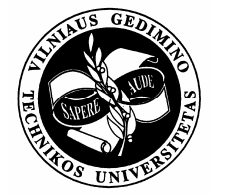

\title{
STRESS-STRAIN ANALYSIS IN THE SOIL SAMPLE DURING LABORATORY TESTING
}

\author{
Neringa Verveckaite ${ }^{1}$, Jonas Amsiejus ${ }^{2}$, Vincentas Stragys $^{3}$ \\ Dept of Geotechnical Engineering, Vilnius Gediminas Technical University, \\ Sauletekio al.11,LT-10223 Vilnius, Lithuania.E-mail: ${ }^{1}$ nidavera@yahoo.com; \\ ${ }^{2}$ jonas.amsiejus@st.vtu.lt; ${ }^{3}$ vincentas.stragys@st.vtu.lt \\ Received 23 Nov 2005; accepted 11 Sept 2006
}

\begin{abstract}
During the determination of soil strength and compressibility in a laboratory by different apparatus soil is loaded in a different way. It has an influence on stress-strain distribution in a sample. Some factors are not evaluated during the results interpretation, for example, friction between soil and device metal parts. The finite-element method analysis also shows that during triaxial, oedometer, shear box tests distribution of stress and strain in the sample is nonuniform. A special apparatus was designed and used for determining horizontal component of stress in the cross-section of the sample. It was determined for sands that horizontal component of stress in the cross-section centre is significantly smaller than at the edges. Increasing load plastic deformations are developing not in the whole sample but in particular places. If we know a real distribution of stress and strain in the sample, it is possible to determine the soil strength and deformation parameters in a more precise way or to rate the influence of different factors on soil properties.
\end{abstract}

Keywords: stress-strain distribution, triaxial test, oedometer, shear box, finite-element method, soil strength.

\section{Introduction}

Mechanical properties of soils were determined by different types of apparatus. Different stress-strain distribution was obtained using various apparatus. Boundary conditions are not distinct when analysing soil samples by oedometer and shear box. It is not obvious a stress distribution within oedometer soil specimen when applying vertical load, a part of vertical load descends to shear ring pane. Not all vertical load applied to top of shear box specimen is transmitted to soil. It is not evident the regularity of change of normal stresses on a shear plane. If an oedometer test is analysed, stress distribution in soil sample depends on the following: manner of load transmission, manner of ring embedding in apparatus (with fixed or floating ring). If a shear box test is analysed, the stress distribution depends on the following: manner of vertical load transmission, position of the mobile part of shear ring, horizontal displacement of the mobile part of the ring.

It is more precise to model stress and strain state in the soil using a triaxial apparatus. Triaxial test is the most widely used test method for determining the strength and stress-strain properties of soil. It is assumed that soil specimen deforms uniformly during the test. The uniformity of stress and strain in the specimen is the main idea of triaxial test. However, it is not often the case that a specimen in triaxial apparatus deforms uniformly during the test. Non-uniformity can be caused by the end restraint, insufficient drainage, membrane effects, soil compression, preparation of soil specimen, self-weight [1-5]. What is stress and strain distribution in soil sample, when a load is transmitted in a provided way? What influence does a non-uniformity have on the strength and stressstrain parameters of soil?

\section{Review of references of laboratory testing}

K. H. Head suggests that due to friction near the platens a so-called „,dead zone“ is formed between triaxial sample ends and the platens [6]. That ,dead zone" causes a non-uniform distribution of stress and strain and nonuniform distribution of pore pressure in case of an undrained test. The use of lubricated ends eliminates ,the dead zones" and protects from a wrong increase in measured strength due to the end restraint. The length of sample should be decreased from the standard ratio of height and diameter $2: 1$ to $1: 1$. This decrease is necessary to ensure an effective lubrication. It influences a more uniform stress and strain distribution [6-8], the sample may retain its cylindrical shape even at large strains. Measured strains and volume changes at failure are larger and probably demonstrate the behaviour of soil mass than those from conventional tests. Another advantage of eliminating friction is that it decreases lateral forces on triaxial cell piston [6].

Triaxial sample end restraint protects the sample from moving sideways freely and causes shear stress at the ends of the sample. Thus, the stress and strain states are not uniform within the sample. Therefore there are difficulties in interpreting test results. Experiments findings showed an influence of end restraint on shear strength of soils. The difference between the shear strength of soil sample, when the friction is eliminated by 
lubricating platen ends, is not considerable if the height and diameter ratio (H/D) of the sample is larger than 2 . Norris, Lee, Lade, Rowe ir Barden found that in the samples with a H/D ratio of 2 to 1 without friction the volume change at failure is higher by about $1-1,5 \%$ than in those without lubricated ends [6]. Bishop ir Green voted that the dilations of soils are practically the same both in lubricated ends and in those with the friction [9]. These discrepancies may be caused by the difference of axial strains at failure. Discrepancies of this kind were also found in previous studies. Raju and his colleagues presented more reliable explanations for the non-uniform results [10]. For the samples without end lubrication, axial strains and volume change occur in the middle of the sample, while their calculations are made according to the values of the whole sample, even though the latter being lower than those in the middle part.

Lubrication method using silicone between two rubber membranes is sufficiently reliable to eliminate ends restraints in triaxial tests $[11,12]$. Scientists have carried out triaxial tests using Fulung, Ottawa and Tamsui River types of sands. Higher peak strengths were generally found in the samples without lubrication. The volume change of the triaxial sample at failure of the sands, either dilation or compression, were higher in the samples with lubricated ends. The volume changes of the samples with and without end lubrication were rather uniform within the sample before the peak strength was reached. When the peak strength was reached and past, the volume change of the samples without end lubrication at the middle part of the sample was considerably higher. The particle breakage within the samples with lubricated end platens was quite uniform throughout the test. However, the particle breakage within the samples without end lubrication was significantly larger at the middle portion of the sample and after the peak [13].

D. W. Airey suggests that the non-uniformity occurs in triaxial samples during isotropic consolidation. He says that uniformity of deformation and stress can only be guaranteed if frictionless ends are used [14]. B. Jeremic, Z. Yang, S. Sture investigated the behaviour of elasticplastic specimens during testing in a triaxial apparatus. They determined that inclination of end platens can cause significant non-uniformities in stress distribution inside specimen. The specimen is distorted sideways and the plastic zone remains signficantly larger than in the level end platen case. Development of plastic zone for a specimen with fixed level end platens begins in the centre of specimen and remains sizable to the specimen ends. For the specimens with friction ends the plastic zone begins at the ends and extends to middle of specimen [15].

H. Sun, J. F. Chen, X. R. Ge used computerised tomography or commonly known by its medical name an $\mathrm{X}$-ray scanner. This method demonstrates the attenuation of an X-ray through soil specimen and density of specimen. The lower density bands appeared in the centre of specimen at a lower confining pressure and spread to the edge due to the weak internal coherence. At higher confining pressure the lower density bands started at the edge and spread to the centre of triaxial due to strong internal coherence of sample [16]. J. Otani, T. Mukunoki, M. Yoshimura also used a new triaxial compression apparatus with the X-ray scanner. After consolidating, the initial condition of the soil sample was scanned before applying the compression. According to the initial condition, the sample cannot be considered homogeneous due to insufficient saturation. The density around the centre of the sample is lower. Low density zones first form in the middle of the sample, later other low density zones start and that is strain localisation. It is simple to determine that the local shear areas start from the bottom of the sample and expand towards the sample edges. With the strains increasing, the shear areas of the sample go upwards, from the bottom of the sample towards the top [17].

C. K. Januskevicius and E. Vey for measuring stresses and strains in triaxial sample used embedded gauges. Samples were $12,7 \mathrm{~cm}$ in diameter and $27,94 \mathrm{~cm}$ in height. They were vertically loaded at constant rate of strain and confined by horizontal pressure. The results of the straingauge show a non-uniformity of strain along the sample length. In the middle of the sample (at its axis) the strains were found to be higher than the average ones, whereas they were less than average at the distance of $3,81 \mathrm{~cm}$ from the sample ends (at its axis). The strains were lower at the distance of $3,81 \mathrm{~cm}$ from the sample bottom than at the same distance from the sample top (at its axis). The strains were gauged at mid-height of the sample and at $3,81 \mathrm{~cm}$ radius positions from the sample centre. The results demonstrate that strains at the centre of the sample are only insignificantly larger than those at the edge [18].

A. Drescher and I. Vardoulakis maintain that bulging and shear band formation depend on the sample density. A dense sample is more sensitive to these forms of strain inhomogeneities [19]. Researchers presume that in medium-dense and loose sand samples shear bands do not appear and the sample may be deformed uniformly even at large strains [20].

Strength and deformation parameters depend on stress-strain distribution in the case of the symmetrical stress distribution about axis. Using stresses $\sigma_{2}=\max$ and in other case $\sigma_{2}=\mathrm{min}$, different soil mechanical properties are obtained [21].

D. Sheng and his colleagues analysed soil stress and strain inhomogeneities in a triaxial sample caused by end restraint in drained and undrained tests, also at insufficient drainage in drained test. The stresses were measured in three aspects. First, when the soil sample end, contact with platen is perfectly smooth, without friction (SC) (Fig $1 \mathrm{a}, \mathrm{d}$, $\mathrm{g}$ ); secondly, when there is friction (FC) between sample ends and platens (Fig $1 \mathrm{~b}, \mathrm{e}, \mathrm{h}$ ); and third, when the contact is rough (RC) (Fig $1 \mathrm{c}, \mathrm{f}, \mathrm{i}$ ). For that purpose a slightly overconsolidated Swedish clay was used. The analysis was carried out using numerical method, by applying the commercial program ABAQUS [1].

The distribution of effective axial stress $\sigma_{a}^{\prime}(\mathrm{kPa})$ in specimens for drained tests can be seen in Fig 1 (qualitative view). The maximum values of effective axial stresses take place at the end edges and the minimum near $-1 / 2$ height of the lateral surface of the specimen [1]. 


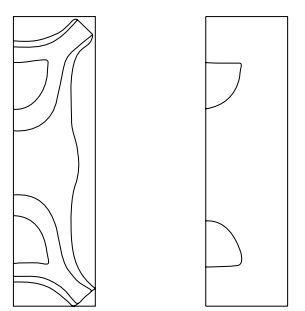

a) $\mathrm{SC}, \varepsilon_{\mathrm{a}}=10 \%$ b) FC, $\varepsilon_{\mathrm{a}}=10 \%$ c) RC, $\varepsilon_{\mathrm{a}}=10 \%$

d) SC, $\varepsilon_{\mathrm{a}}=25 \%$ e) FC, $\varepsilon_{\mathrm{a}}=25 \%$ f) RC, $\varepsilon_{\mathrm{a}}=25 \%$

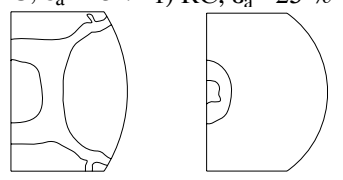

g) SC, $\varepsilon_{\mathrm{a}}=50 \%$ h) FC, $\varepsilon_{\mathrm{a}}=50 \%$ i) RC, $\varepsilon_{\mathrm{a}}=50 \%$

Fig 1. Distribution of effective axial stress $\sigma_{a}^{\prime}(\mathrm{kPa})$ in specimens for drained tests

\section{Theoretical analysis of stress distribution in soil specimen using a numerical method}

In order to analyse stress and strain distribution in soil sample during the oedometer and shear box tests a numerical modelling was carried out by COSMOS/M programme. A finite element models are presented to simulate the testing procedures. The formulation of a linear static problem for solution by the displacement method is fully described by the matrix equation:

$$
[K]\{\boldsymbol{U}\}=\{\boldsymbol{F}\},
$$

where $[K]$ - the structural (assembled) stiffness matrix; $\{\boldsymbol{U}\}$ - the vector of unknown nodal displacements; $\{\boldsymbol{F}\}-$ the load vector.

The nodal displacements are calculated according to formula:

$$
\{\boldsymbol{U}\}=[K]^{-1}\{\boldsymbol{F}\} .
$$

Then the vector of elements nodal displacements $\left\{\mathbf{u}_{k}\right\}$ is found. By using the matrix of elements geometrical properties $\left[B_{K}\right]$, the elements deformations are obtained:

$$
\left\{\boldsymbol{\varepsilon}_{K}\right\}=\left[B_{k}\right]\left\{\mathbf{u}_{K}\right\} .
$$

The stresses of finite elements are obtained, when elements deformations and stiffness matrix of elements material $\left[K_{\text {elem }}\right]$, in which the information about characteristics of material elasticity $E, v$, is known:

$$
\left\{\boldsymbol{\sigma}_{K}\right\}=\left[K_{\text {elem }}\right]\left\{\boldsymbol{\varepsilon}_{K}\right\} \text {. }
$$

The following parameters were used for the sand specimen: elasticity modulus - $20 \mathrm{MPa}$, mass density -
$1,85 \mathrm{Mg} / \mathrm{m}^{3}$, Poisson's ratio - 0,3. The oedometer sample, $0,0875 \mathrm{~m}$ in diameter and $0,035 \mathrm{~m}$ in height, was discretised into 4-node two dimensional elements (Fig 2) with symmetric loading. Only two translational degrees of freedom per node were considered for structural analysis. Two principal diagrams were designed: a) oedometer with fixed ring and stiff stamp, displacement $u_{y}=$ const uniformly vertically acts on the top surface of the oedometer; b) oedometer with fixed ring and flexible stamp, vertical component of stress $\sigma_{y}=$ const uniformly acts on the top surface of the oedometer.

The soil sample of the shear box with a stiff stamp, 0,071 in diameter and 0,035 in height, was discretised into 4-node tetrahedral elements (Fig 3). Three translational degrees of freedom per node were considered for structural analysis. Displacement $u_{y}=$ const uniformly vertically acted on the top surface of the model.

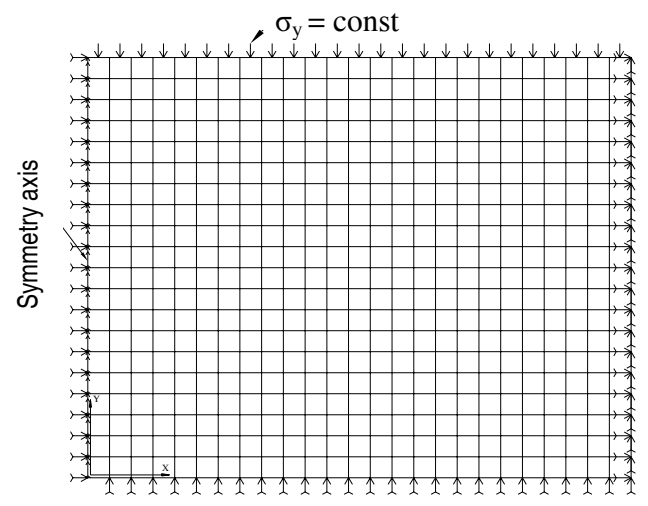

Fig 2. Finite elements representation of the oedometer sample

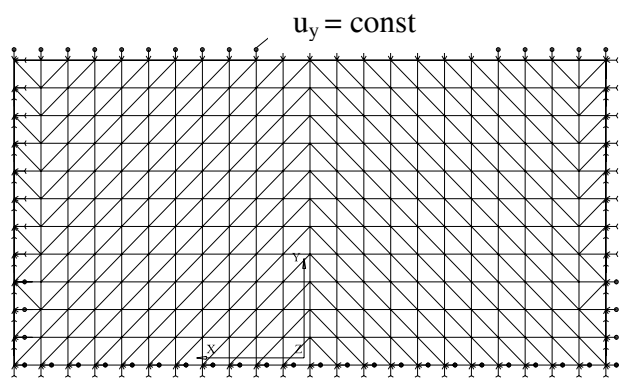

Fig 3. Finite elements representation of the sample during the shear box test

While analysing the oedometer sample by numerical method, it was found that shear stress distribution in the sample was not uniform, and thus the vertical component of stress distributed also non-uniformly (Fig 4). A part of vertical load descends to shear ring pane. When the oedometer was analysed with the fixed ring and stiff stamp, it was obvious that whole sample is affected by the stress of compression and the upper corner by the stress of tension (Fig 5). 


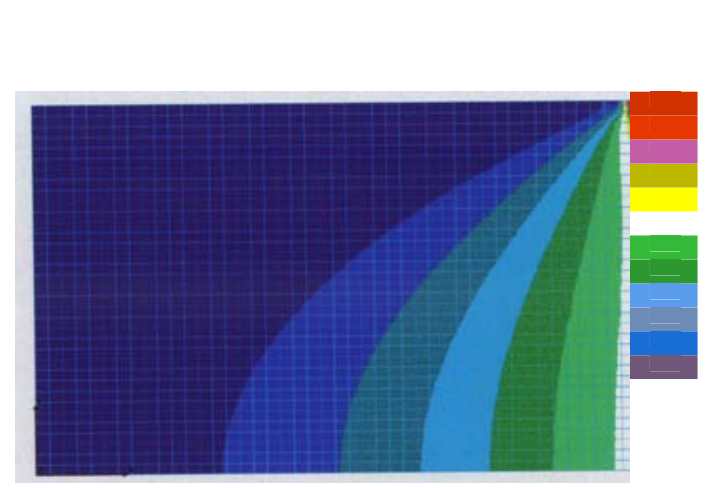

Fig 4. Distribution of vertical component of stress $\sigma_{y}$ in the sample if analysed by oedometer with a fixed ring and flexible stamp (linear model)

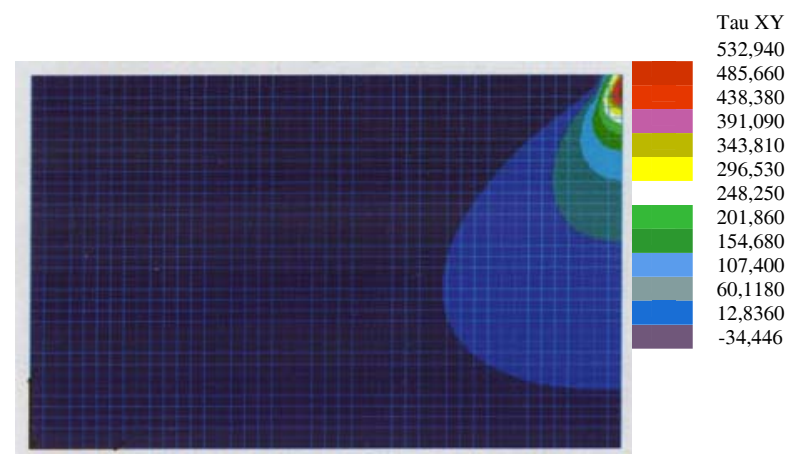

Fig 5. Shear stress $\tau_{x y}$ distribution in the sample if analysed by oedometer with a fixed ring and stiff stamp (linear model)

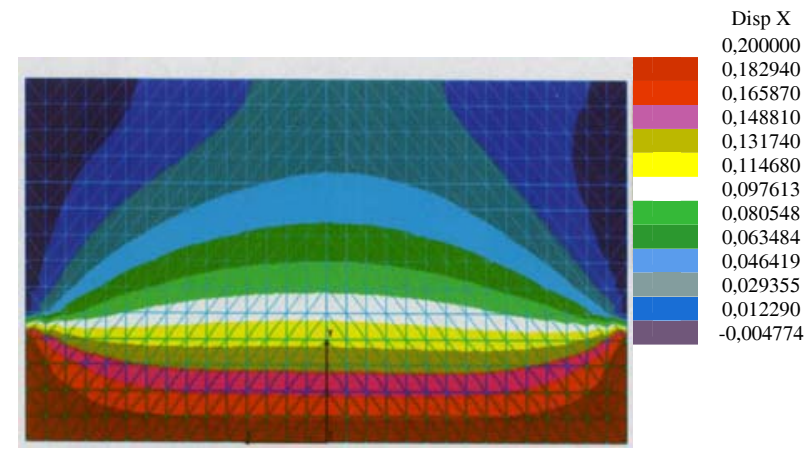

Fig 6. Horizontal soil displacements $u_{x}$ distribution during shear box test using stiff stamp (linear model)

The stress and strain distribution in soil sample during the shear box test is non-uniform [22-25]. Applying a numerical method, horizontal soil displacements $u_{x}$ in soil sample during shear box tests were analysed using stiff and flexible stamps. In Fig 6 we can see that the horizontal soil displacements $u_{x}$ in shear box distribute non-uniformly. Fig 7 shows that vertical soil displacements reflect stamp turn: one side of stamp rises, the other - falls. Experiments demonstrate the same results.

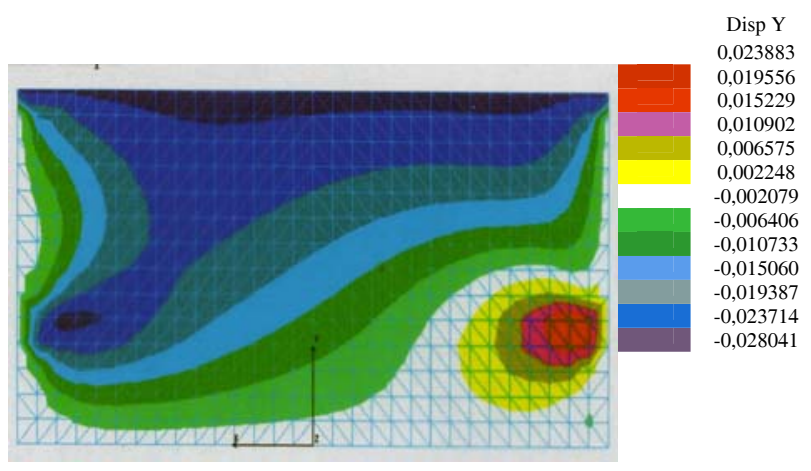

Fig 7. Vertical soil displacements $u_{y}$ distribution during shear box test using stiff stamp (linear model)

\section{Experimental analysis of stress distribution in soil specimen during triaxial tests}

\subsection{Physical and mechanical properties of testing soil}

The fine sand was tested in this work. Name of soil according with Unified Soil Classification System is poorly-graded sand with fine SP-SM. Particles of sand are of rounded shape. The sand has an uniformity coefficient of 3,03 , curvature coefficient 1,47 , a specific gravity of soil particles of 2,671, maximum void ratio of 0,7446 , minimum void ratio of 0,5706 , density index 0,83 . The grain size distribution of the sand is shown in Fig 8.

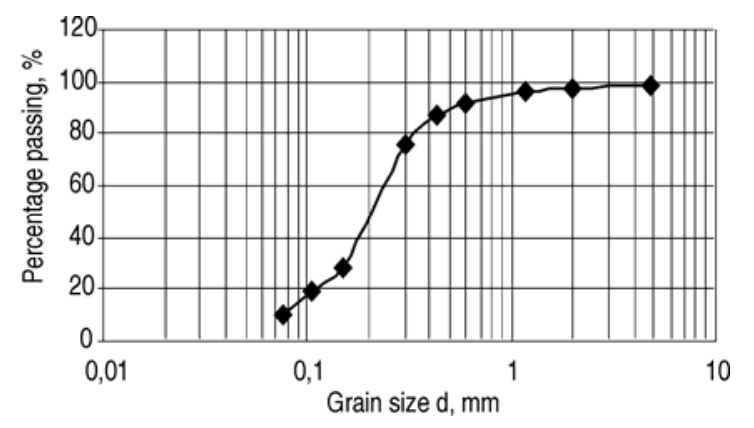

Fig 8. Grading curve of fine sand

The specimens for triaxial tests were prepared of dry sand with $6 \%$ wet by tamping. The diameter of specimens was nearly equal to $5 \mathrm{~cm}$, the height-diameter ratio being about 2 . All shear tests were performed in a conventional triaxial cell under undrained (CU tests) conditions. The $\mathrm{CU}$ tests were performed under cell effective pressure $\sigma_{3}$ of $50 \mathrm{kPa}, 100 \mathrm{kPa}, 200 \mathrm{kPa}$. The experiments were carried out at a constant cell pressure and constant axial strain rate. During the test, axial deformation, volume change, force and pore water pressure were measured (Figs 9, 10). Fig 9 shows the relationship between a principal stress difference $\left(\sigma_{1}-\sigma_{3}\right)$ and axial strain $\varepsilon_{\mathrm{a}}$ of $\mathrm{CU}$ test. The deviator stress at failure is found to increase with cell pressure. This increase becomes progressively smaller as the water in the voids is compressed, and ceases when the stresses are large enough. 
The loading path is given in Fig 11. The Mohr envelope for a series of CU tests on sand specimens is shown in Fig 12. $c$ and $\phi$ according to experimental findings were calculated.

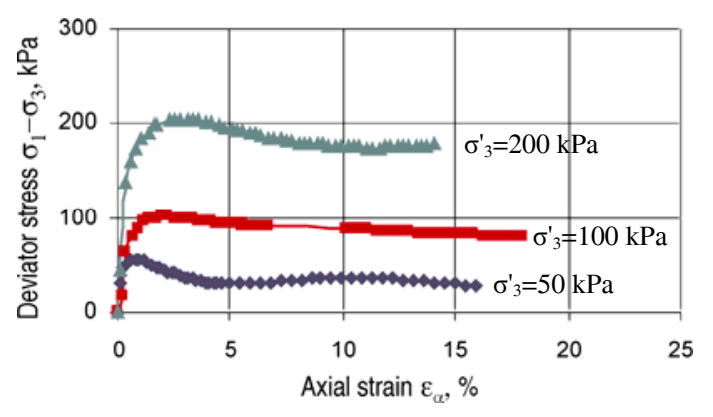

Fig 9. Deviator stress against strain of CU triaxial compression test

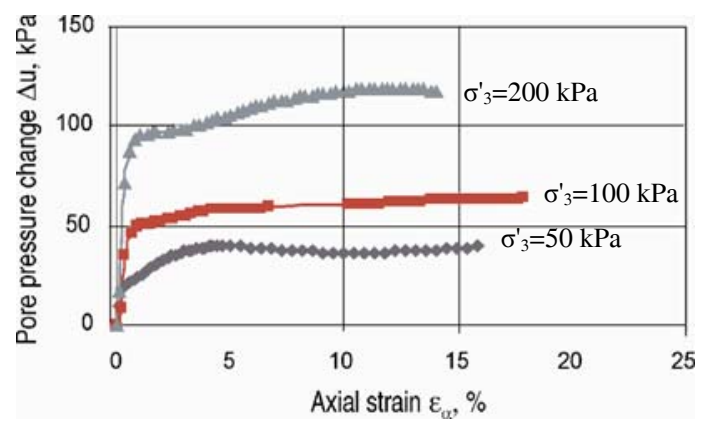

Fig 10. Pore pressure change against strain of CU triaxial compression test

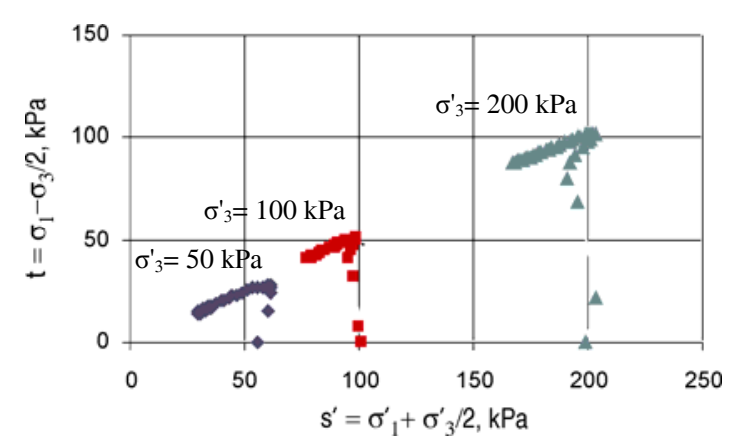

Fig 11. Stress path of CU triaxial compression test

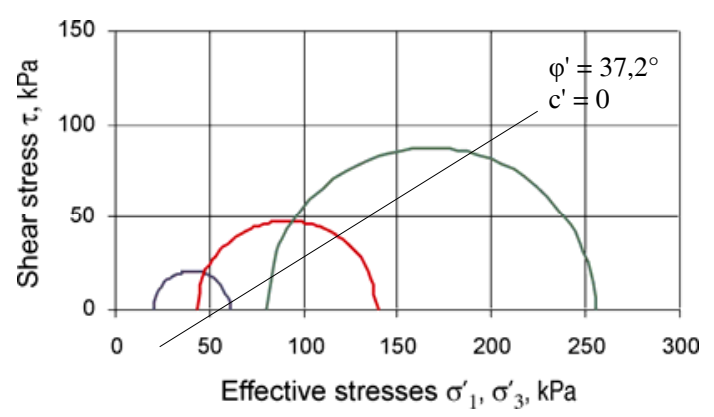

Fig 12. Mohr circles of CU tria12xial test

\subsection{Experimental tests}

In geotechnical laboratory a device was designed to analyse the non-uniform deformation of soil specimen caused by such factors as compaction of soil specimen, soil grading, shape and orientation of soil particles, magnitude of load etc.

The device consists of a metal cylinder of $15 \mathrm{~cm}$ in diameter and $45 \mathrm{~cm}$ height -1 , inside which there is a rubber membrane -2 . Metal cylinder was filled with a soil -3 . Inside the soil a steel strip $-4,20 \mathrm{~mm}$ width and $0,5 \mathrm{~mm}$ thick was inserted. Steel strip was placed in 3 positions: in the centre of soil $\mathrm{A}$ and in the sides of soil $\mathrm{B}$ and C (Fig 13). After cylinder was filled with a soil, ends of cylinder were closed with plates -5 . Plates were screwed in order to stop leakage of air pressure. A sample of soil was subjected to an air pressure in the horizotal direction. Then the steel strip was loaded step by step by a vertical load till finally pulled out.

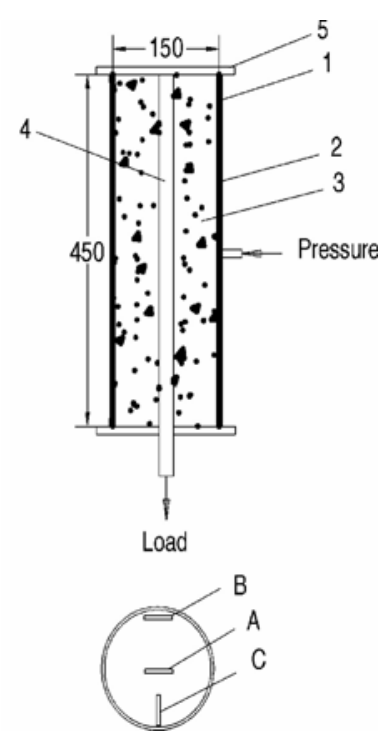

Fig 13. The designed device to analyse the non-uniform deformation of soil specimen during triaxial test: $1-$ metal cylinder; 2 - rubber membrane; 3 - soil sample; 4 - steel strip; 5 - fixed metal plate

The same fine sand like triaxial sample and fine granite crushed stone of $0,5 \mathrm{~mm}$ were used for experiments. Soil samples were compacted and subjected to $25 \mathrm{kPa}$, $50 \mathrm{kPa}, 75 \mathrm{kPa}$ of confining air pressure. The density of sand $1,7 \mathrm{t} / \mathrm{m}^{3}$, void ratio 0,6 . The density of fine granite crushed stone $1,4 \mathrm{t} / \mathrm{m}^{3}$, void ratio 0,95 . Six experiments were carried out in one hole applying different confining air pressure. The experiment findings are presented in Figs 14-18. Experimental findings show that horizontal component of stress $\sigma_{x}$ inside soil sample is distributed non-uniformly. Larger horizontal component of stress was found in the sides of soil specimen (side holes B,C) and smaller was found in the centre of soil specimen (middle hole-A). Figs 14, 16, 17, 18 show stresses, when steel strip from sand specimen was pulled out about 1-3 centimeters (continuous line) at first, and finally (dotted line) was pulled out at a larger force. It is not evident why. 
Three types of samples with the density of $1,65 \mathrm{t} / \mathrm{m}^{3}$ were prepared in order to estimate the influence of vertical component of stress on stress distribution in the soil samples. First sample, cylinder was full of sand (Figs 14, 16 ); the second sample, it is slightly more of sand in the cylinder than its length (Fig 17); the third sample contains slightly less sand in the cylinder than its length (Fig 18). Experimental results did not show an obvious influence. Displacements were not measured.

The pull-out force from fine granite crushed stone was larger, because its particles had a sharp shape. Thus, friction between a steel strip and particles of fine granite crushed stone was higher than between the steel strip and sand.

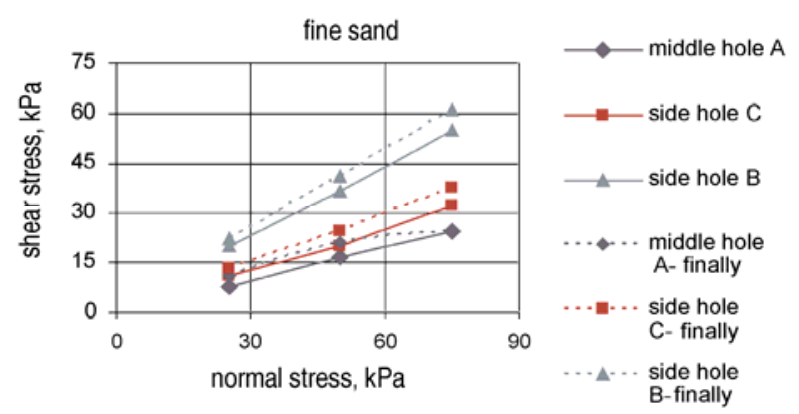

Fig 14. Distribution of horizontal component of stress $\sigma_{x}$ during the test of sand sample

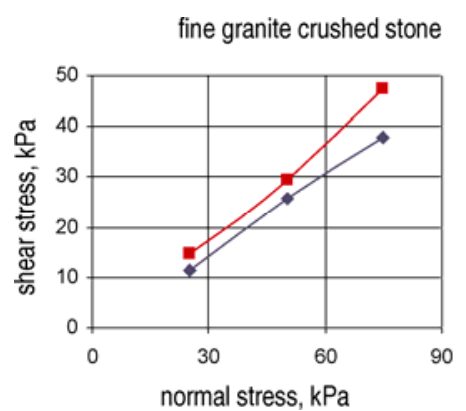

$\multimap$ middle hole A $\rightarrow$ side hole C

Fig 15. Distribution of horizontal component of stress $\sigma_{x}$ during test of fine granite crushed stone

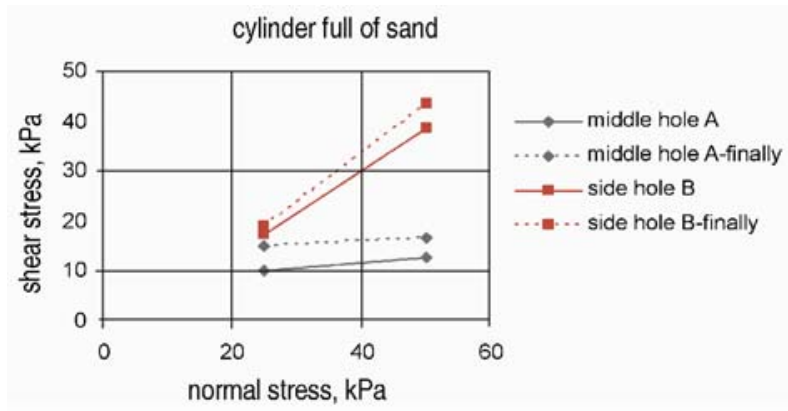

Fig 16. Distribution of horizontal component of stress $\sigma_{x}$ in soil sample triaxial test if cylinder is full of sand

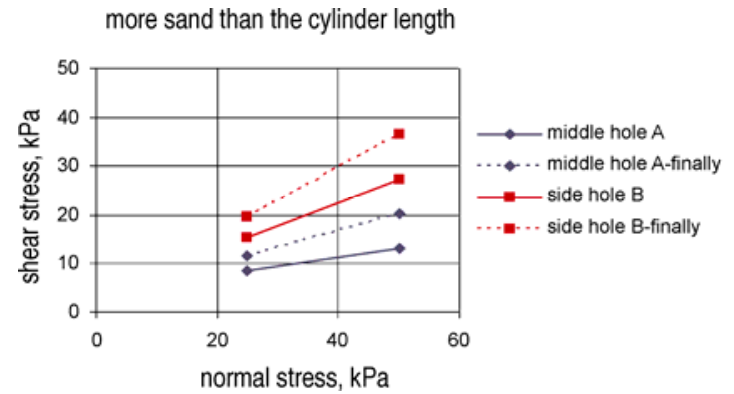

Fig 17. Distribution of horizontal component of stress $\sigma_{x}$ during test if there is slightly more sand in the cylinder than its length

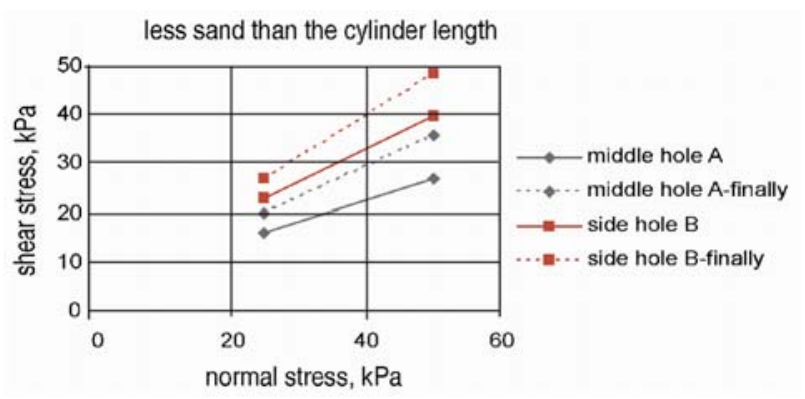

Fig 18. Distribution of horizontal component of stress $\sigma_{x}$ during test if there is slightly less sand in the cylinder than its length

\section{Conclusions}

1. Mechanical properties of soils depend on construction of apparatus. Using different types of apparatus different stress-strain distribution was obtained.

2. The analysis of vertical component of stress $\sigma_{y}$ using the numerical method demonstrates a non-uniform distribution in soil specimens during oedometer, shear box and triaxial tests.

3. From the results of tests carried out in the laboratory it is obvious that horizontal component of stress $\sigma_{x}$ inside triaxial soil sample is distributed non-uniformly. Larger horizontal component of stress was found at the sides of soil specimen and smaller in the centre of soil specimen.

4. Analysis of references show that stress distribution in the triaxial soil samples are influenced by the friction between platens and sample ends.

5. Further experiments should be carried out in order to analyse stress distribution in the sample depending on soil density, soil grading, shape and orientation of soil particles, magnitude of load, ways of sample preparation, sample height and diameter ratio, friction between platens and sample ends etc.

\section{References}

1. SHENG, D.; WESTERBERG, B.; MATTSSON, H.; AXELSSON, K. Effects of end restraint and strain rate in triaxial tests. Computers and Geotechnics, 21 (3), 1997, p. 163-182. 
2. AL-CHALABI, M.; HUANG, C. L. Stress distribution within circular cylinders in compression. International Journal of Rock and Mining Science \& Geomechanics Abstracts, 11 (2), 1974, p. 45-56.

3. DONG, J.; NAKAMURA, K. Anisotropic deformation and strength characteristics of gravels in large-scale plane strain and triaxial compression tests. In Proc of the 14th International Conference on Soil Mechanics and Foundation Engineering. Hamburg, Sept 6-12, 1997, p. 81-84.

4. LA ROCHELLE, P.; LEROUEIL, S.; TRAK, B.; BLAISLEROUX, L.; TAVENAS, F. Observational approach to membrane and area corrections in triaxial tests. In Advanced triaxial testing of soil and rock. ASTM STP 977, Donaghe, R. T.; Chaney, R. C.; Silver, M. L. Philadelphia, 1988, p. 715-731.

5. SAUSSUS, D. R.; FROST, D.; ASHMAWY, A. K. Variations in membrane contact patterns of reconstituted sand specimens. Geotechnical Testing Journal, 23 (4), Dec 2000, p. 522-531.

6. HEAD, K. H. Manual of soil laboratory testing. Vol 3: Effective stress tests. London, 1986, p. 743-1238.

7. LADE, P. V.; WASIF, U. Effects of height-to-diameter ratio in triaxial specimens on the behaviour of crossanisotropic sand. In Advanced triaxial testing of soil and rock. ASTM STP 977, Donaghe, R. T.; Chaney, R. C.; Silver, M. L. Philadelphia, 1988, p. 706-714.

8. GOTO, S.; TATSUOKA, F. Effects of end conditions on triaxial compressive strength for cohesionless soil. In $A d$ vanced triaxial testing of soil and rock. ASTM STP 977, Donaghe, R. T.; Chaney, R. C.; Silver, M. L. Philadelphia, 1988, p. 692-705.

9. BISHOP, A. W.; GREEN, G. E. The influences of end restraint on the compression strength of a cohesionless soil. Geotechnique, 15 (3), 1965, p. 243-265.

10. RAJU, V. S.; SADASIVAN, S. K.; VENKATARAMAN, M. Use of lubricated and conventional end platens in triaxial tests on sands. Soils and Foundations, 12 (4), 1972, p. 35-43.

11. TATSUOKA, F.; MOLENKAMP, F.; TORII, T.; HINO, T. Behaviour of lubrication layers of platens in elements tests. Soils and Foundations, 24 (1), 1984, p. 113-128.

12. HETTLER, A.; GUDEHUS, G. Discussion. Soils and Foundations, 25(3), 1985, p. 140.

13. UENG, T.-S.; TZOU, Y.-M.; LEE, C.-J. The effect of end restraint on volume change and particle breakage of sands in triaxial tests. In Advanced triaxial testing of soil and rock. ASTM STP 977, Donaghe, R. T.; Chaney, R. C.; Silver, M. L. Philadelphia, 1988, p. 679-691.

14. AIREY, D. W. Finite element analyses of triaxial tests with different end and drainage conditions. In Proc of the 7th International Conference on Computer Methods and Advances in Geomechanics. Vol 1. Balkema, Rotterdam, 1991, p. 225-230.

15. JEREMIC, B.; YANG, Z.; STURE, S. Numerical assessment of the influence of end conditions on constitutive behaviour of geomaterials. Journal of Engineering Mechanics, 130 (6), June 2004, p. 741-745.

16. SUN, H.; CHEN, J. F.; GE, X. R. Deformation characteristic of silty clay subjected to triaxial loading by computerised tomography. Geotechnique, 54 (5), 2004, p. 307314

17. OTANI, J.; MUKUNOKI, T.; YOSHIMURA, M. Development of new triaxial compression test apparatus for geomaterials on industrial X-ray CT scanner. In Proc of the 15th International Conference on Soil Mechanics and Geotechnical Engineering. Istanbul, 27-31 Aug 2001, p. 231-234.

18. JANUSKEVICIUS, C. K.; VEY, E. Stress and strains in triaxial specimens. Instruments and apparatus for soil and rock mechanics, ASTM special technical publication No 392, American Society for Testing and Materials. Philadelphia, 1965, p. 169.

19. BALEVICIUS, R.; DZIUGYS, A; KACIANAUSKAS, R. Discrete element method and its application to the analysis of penetration into granular media. Journal of Civil Engineering and Management, 11 (2), 2004, p. 3-14.

20. VARDOULAKIS, I.; DRESCHER, A. Behaviour of granular soil specimens in the triaxial compression test. Developments in soil mechanics and foundation engineering. Elsevier, 1985. $281 \mathrm{p}$.

21. MECSI, J. Alteration of soil stress/strain condition in the surrounding of the base of pile. In Proc. of the 11th International Conference on Computer Methods and Advances in Geotechnics. Torino, 19-24 June 2005, p. 515-523.

22. ALLERSMA, H. G. B. Optical analysis of stress and strain in shear zones. Available at http://geo.citg.tudelft.nl/allersma /allersma2.pdf (Accessed:2005, February)

23. ALIKONIS, A.; AMŠIEJUS, J.; STRAGYS, V. Improvement of shear box apparatus and methodology of test. In Proc of the 12th European Conference on Soil Mechanics and Geotechnical Engineering. Amsterdam, 7-10 June 1999, p. 1053-1057.

24. AMŠIEJUS, J. Determination design values of soil strength parameters (Grunto stiprumo rodikliu skaičiuojamuju reikšmiu nustatymas). Summary of $\mathrm{PhD}$ thesis. Vilnius: Technika, 2000. 48 p. (in Lithuanian).

25. AMŠIEJUS, J. Analysis of methods for determining soil shear strength design. Statyba (Civil Engineering), 6 (2), 2000, p. 120-127 (in Lithuanian).

\section{İTEMPIMŲ BŪVIO GRUNTO BANDINIUOSE, TIRIANT JUOS LABORATORINĖMIS SĄLYGOMIS, ANALIZE}

\section{N. Vervečkaitė, J. Amšiejus, V. Stragys}

Santrauka

Tiriant gruntu mechanines savybes laboratorijoje kiekviename aparate bandinys apkraunamas skirtingai. Tai turi itakos itempimų ir deformacijų pasiskirstymui bandinyje. Interpretuojant bandymo duomenis ignoruojami kai kurie veiksniai, turintys įtaką įtempimams pasiskirstyti, pvz., bandinio galinių plokštumų ir štampo trinties jègos tiriant gruntą triašio slègio aparate, bandinio ir žiedo trinties jègos tiriant gruntą odometre ar tiesioginio kirpimo aparate. Itempimu pasiskirstymo skaitiniu modeliavimu nustatyta, kad ne tik odometre bei tiesioginio kirpimo aparate, bet ir triašio slègio aparate bandinio ittempimo būvis nèra vienodas. Sukonstruotas prietaisas, kuriuo galima įvertinti itempimu horizontaliosios komponentės kitimą bandinio skerspjūvyje. Tiriant smèlini gruntą gauta, kad įtempimų horizontaliosios komponentès reikšmė bandinio centre yra gerokai mažesnè nei taškuose arti šoninio paviršiaus. Plastinių deformacijų didinant apkrovą atsiras ne visame 
bandinyje, o tik tam tikruose jo taškuose. Žinant tikraji itempimų ir deformacijų pasiskirstymą bandinyje, bus galima tiksliau nustatyti grunto mechaninių savybių rodiklius arba įvertinti tam tikrų veiksnių įtaką grunto savybių rodikliams.

Reikšminiai žodžiai: įtempimų ir deformacijų pasiskirstymas, triašio slėgio aparatas, odometras, tiesioginio kirpimo aparatas, skaitinis modeliavimas, grunto mechaninių savybių rodikliai.

Neringa VERVECKAITE. PhD student at the Dept of Geotechnical Engineering at Vilnius Gediminas Technical University, Lithuania. Research interests: stress and strain distribution in the soil sample during laboratory testing, triaxial testing.

Jonas AMSIEJUS. Dr Assoc Professor at the Dept of Geotechnical Engineering at Vilnius Gediminas Technical University, Lithuania. Research interests: various topics of estimation of soils mechanical properties, stress and strain state, practical aspects of using probabilistic and statistical analysis and design methods for structures and foundations.

Vincentas STRAGYS. Dr Assoc Professor. Head of Geotechnical Dept of Vilnius Gediminas Technical University. Partner of Framework 5 research project "GeoTechNet". Vice-Chairman of Lithuanian Association of Civil Engineers and Chairman of Technical Committee "Geotechnics" at Lithuanian Standards Board. Research interests: geotechnical investigation and testing soils, triaxial testing, research in to standardisation in geotechnics. 